PNL-2514

UC-60

\title{
A Wind Prospector's Instrument
}

by

Philip A. Ekstrom

M. Gary Verholek

\section{April 1978}

Pacific Northwest Laboratory

Richland, Washington 99352

Operated for the

U.S. Department of Energy

by 
NOTICE

This report was prepared as an account of work sponsored by the United States Government. Neither the United States nor the Department of Energy, nor any of their employees, nor any of their contractors, subcontractors, or their employees, makes any warranty, express or implied, or assumes any legal liability or responsibility for the accuracy, completeness or usefulness of any information, apparatus, product or process disclosed, or represents that its use would not infringe privately owned rights.

The views, opinions and conclusions contained in this report are those of the contractor and do not necessarily represent those of the United States Government or the United States Department of Energy.

\author{
PACIFIC NORTHWIEST LABORATORY \\ operated by \\ BATTELLE \\ for the \\ UNITED STATES DEPARTMENT OF ENERGY \\ Under Contract EY-76-C-06-1830
}

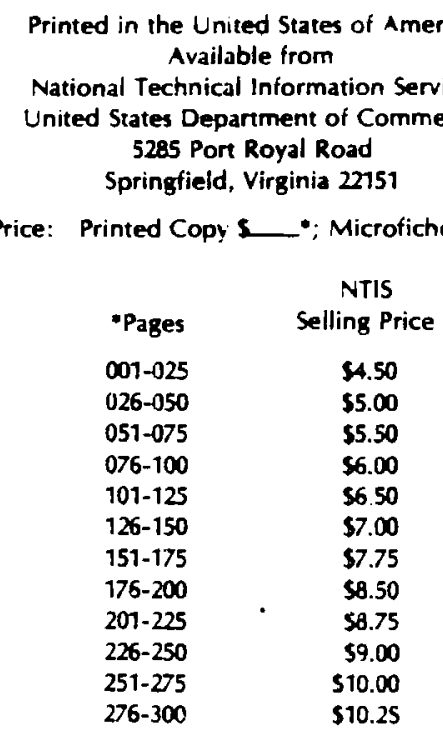


PNL -2514

33679000492050

$\mathrm{UC}-60$

A WIND PROSPECTOR'S INSTRUMENT

by

Philip A. Ekstrom

M. Gary Verholek

April 1978

PACIFIC NORTHWEST LABORATORY

Richland, washington 99352

Operated by

BATTELLE MEMORIAL INSTITUTE

Prepared for the U.S. Department of Energy under Contract EY-76-C-06-1830. 
A WIND PROSPECTOR'S INSTRUMENT

Philip A. Ekstrom

M. Gary Verholek

In the initial evaluation of a prospective wind turbine site, wind measurements must be made at that site. This report describes an inexpensive data collection device that can be used to record such measurements, producing statistical summaries of wind behavior at the site. Prospectors have often used analogous devices to locate deposits of mineral resources; thus, we call this device a wind prospector's instrument.

Of prime interest at a prospective wind turbine site is the total amount of power which could be produced by a given wind turbine. Since that power may be linked to a utility network, or coupled with some other load representing a timevarying demand, the time behavior of the available power is also important. Wind speed and direction information is useful for wind flow patterns in the immediate vicinity of the instrument; short-term directional behavior aides the evaluation of the pointing strategy of a given turbine.

A complete time history of wind speed and direction could be combined with the wind turbine characteristics to provide this information. However, during the initial site evaluation one often cannot afford to either acquire or analyze a detailed wind history. Instead, one must attempt to characterize the the statistical behavior of the wind; therefore, one concentrates on wind characteristics which can be extracted from anemometer and wind vane output without recording and preserving a detailed history. Important statistics are joint frequency distributions of speed and direction, speed and time of day, and speed and dwell-at-speed. Joint distributions can 
be obtained by sampling the wind speed and direction at regular time intervals, counting occurrences of various combinations of speed and direction, speed and time of day, etc. From these joint distributions, averages (and higher moments) can be calculated and combined with the characteristics of any given wind turbine to obtain total power, and power vs. time of day, etc. Turbulence may be characterized by deviations from moving averages of speed or direction. Peak wind statistics are also obtainable.

An instrument which would collect and record this information inexpensively could play a role in locating and evaluating "deposits" of wind energy, much like a geiger counter in locating deposits of uranium. Hence, we refer to it as a wind prospector's instrument. Most of the statistics could be accumulated by relatively simple equipment: an assembly of event counters preceded by classifying and steering circuitry. The wind would be sampled at regular intervals, classified as to state $(\mathrm{e} . \mathrm{g} .$, between 4 and $6 \mathrm{~m} / \mathrm{s})$, and a count kept of the occurrences of each state. An instrument which samples uniformly with respect to wind run instead of time has been constructed and used, 1,2 and other similar devices are commercially available.

When the wind classes are compounded of speed and direction (e.g., between 4 and $6 \mathrm{~m} / \mathrm{s}$ out of the Northwest), the resulting data represent a joint frequency distribution and may be illustrated as either a wind rose for each speed interval, or a frequency distribution for each direction. Such data can help characterize flow patterns in the immediate vicinity of the instrument.

If the classes are compounded of speed and time of day (e.g., between 4 and $6 \mathrm{~m} / \mathrm{s}$, and between midnight and 3 a.m.), an indication is obtained of the diurnal variations in power availability, which can be compared to the diurnal power demand of the intended load. 
A number of manufacturers presently offer multiple accumulators which, with minor modification, could be put into service to accumulate the tallies discussed above. However, none seems to be suited for general prospecting use. There are units now manufactured which can produce joint frequency distributions, or which, with modification, could produce diurnal distributions, but no single unit does both. Also, such instruments are expensive, and most are too bulky, heavy, and/or power consuming to be backpacked to a remote location.

In considering options for building a more suitable instrument, we find that a microprocessor-based device offers by far the greatest flexibility and least complexity. Its cost and power drain are comparable with that of other options employing hard-wired logic. The complexity of keeping a given statistic is embodied in programming, not wires and gates, and one can obtain information under program control, which would be prohibitively costly to hard-wire. The detailed design of such a device is complete, which, in its most elaborate version, can provide all of the statistics needed. This version can be built in reasonable quantity for approximately $\$ 400$. A stripped-down version could be constructed for perhaps half that cost, but would provide only the speed vs. direction histogram, and peak wind.

\section{HARDWARE}

A block diagram of the instrument is shown in Figure 1. A recently introduced single-chip data-acquisition unit (National Semiconductor ADC0816) is used to provide sixteen analog or low-speed digital inputs. Its inputs are assigned to the wind instrument input connector and used to measure potentiometer wiper positions, generator outputs, or contact closures. The unit may be used with all common types of anemometers and wind vanes and is capable of monitoring 


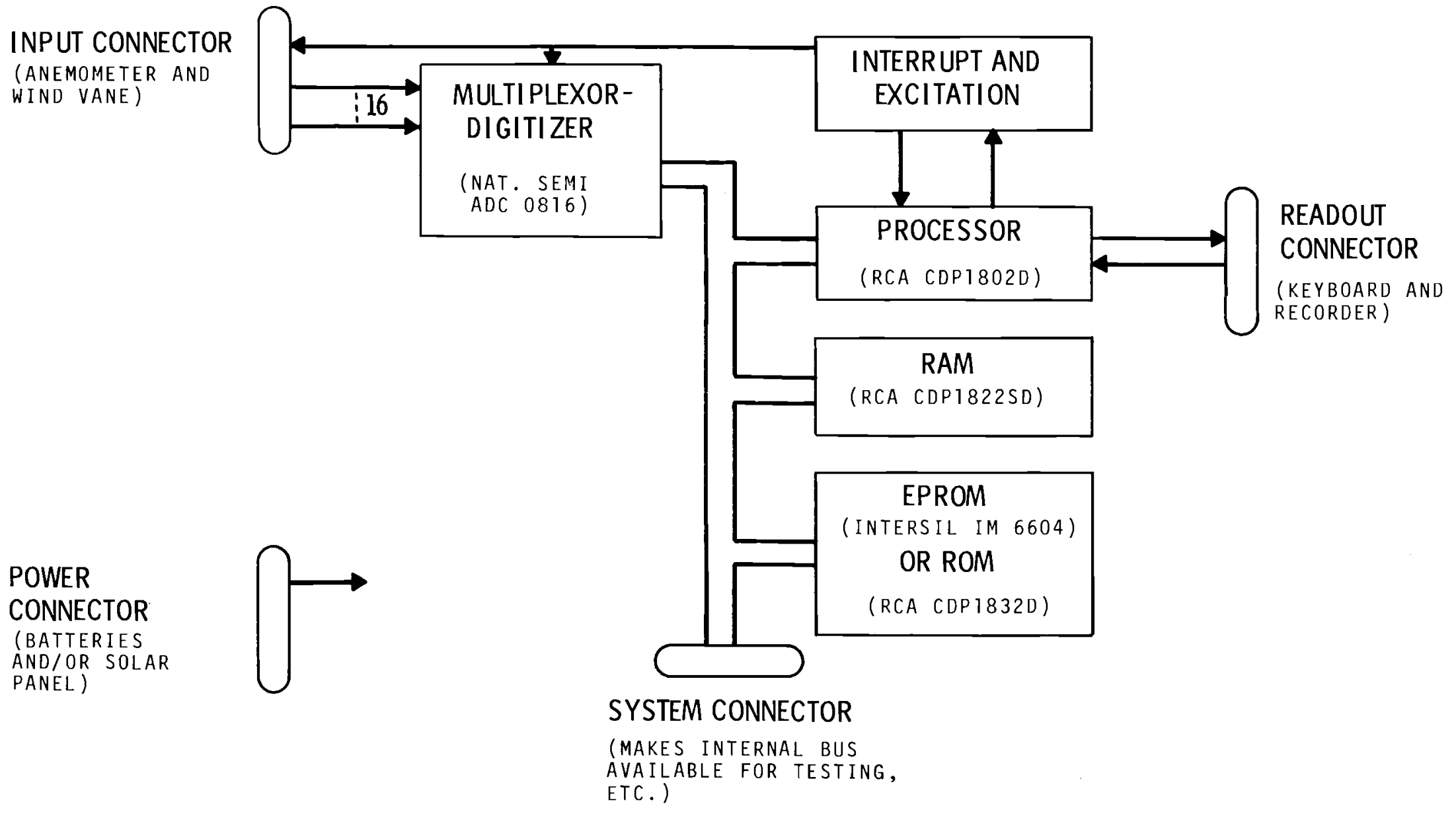

Figure 1. Block Diagram of Wind Prospector's Instrument 
several measurement points at once. In addition to wind data, it can gather such parameters as insolation and temperature. Ratiometric measurements may be made, avoiding the necessity for calibration of the digitizer.

Inputs are scanned once per time interrupt, controlled by a microprocessor. The desired frequency distributions are accumulated in its Random Access Memory (RAM), under control by a program stored in Erasable-Programmable Read only Memory (EPROM) . As a power-saving feature, excitation voltage to potentiometer-type sensors is switched on only when a measurement is to be made, and is turned off by the processor as soon as the sensor has been sampled.

The crystal-controlled processor clock is counted down to determine the interrupt rate, and that rate is counted down in software to provide sampling interval and time of day. The basic unit of timekeeping is $7.5 \mathrm{sec}$, the longest interval which is commensurate with both $1 / 256$ day and 1 minute. The interrupt rate is 298.67 per second, an exact multiple of one per 7.5 seconds, and a nominal match to a serial data output bit rate of 300 per second. This rate allows direct readout on a sampling basis of low-frequency contact type anemometers (60 pulses per mile), and higher frequency types require only minor prescaling.

The processor used is an RCA CDP1802D, which employs Complementary Metal-oxide Semiconductor (CMOS) logic for low power drain. It offers convenient program-load features which allow a portion of the RAM to be loaded with program via the system connector for testing and one-of-a-kind data gathering tasks.

No readout device is included in the field unit. Instead, the processor's serial input and output lines are assigned to a readout connector. At the end of each period, nominally a week or month, a control keyboard and data readout device are 
brought to the field unit and plugged into the connector. Keyboard commands are available for data dump, data clear, time set, etc. Two alternate output devices are planned: one, a small battery-operated printer, the other an ordinary audio tape recorder on which the data are recorded in a modification of the "Kansas City standard" format popular with computer hobbyists.

The completed unit will eventually be a single-printed circuit card which will be housed in a weatherproof enclosure. Ordinarily the entire enclosure will be mounted directly on the instrument tower. Average power requirements will be a few milliamperes at 5 volts, which may be supplied by small primary cells, or by four nickel-cadmium rechargeable cells and a solar panel.

The memories, both RAM and EPROM, dominate the power drain, and RAM will ordinarily dominate the unit cost. The memory select and clock circuitry has been arranged for minimum-power cycling, and the RAM has been organized into four 256-byte blocks so that stripped-down versions are possible.

\section{SOFTWARE}

The first 256 bytes of memory are allocated to a histogram of 16 wind speed classes by eight directions. Each cell comprises two bytes, for a count capacity of 65535 , or one per minute for 40 days. Since no directional data are needed for the "zero-speed" class, 14 bytes of working storage are available for peak wind, timekeeping, counts, flags, etc. As a result, the program may be written to run with only this first memory increment.

The second 256-byte block is normally assigned to a histogram of 16 wind speed classes by eight times of day. The third block holds a histogram of eight speed classes by eight 
values of run duration in speed class. The speed resolution of this histogram will necessarily be blurred by logic used to avoid class edge effects. Otherwise, a fairly steady wind at a class boundary might register as a large number of short dwells in each class.

The fourth memory block is allocated to measures of turlence. A moving average is maintained of wind speed and direction. At appropriate intervals the difference is formed between a new measured value and an average. This value is used to update the average, then is classified to maintain a histogram of deviations from the average. The decay time of the average may be chosen to set the scale of the turbulence, and a slew rate limit may be imposed to model the limited angular following rate of some large turbines. A number of averages and deviation tables will be maintained for each measured quantity, corresponding to various time scales, following rates, etc.

The tables in the first two memory blocks are already well enough defined for a universal program to be written for most single-measurement-point applications. Sensible choices are possible for the run duration and turbulence measurements as well. Once this universal program is verified, it can be committed to mask-programmed RAM for greater economy and lower power drain. A standard prospecting unit is then available for routine application without reprogramming.

\section{READOUT AND DATA HANDLING}

The histograms of the desired joint frequency distributions are expressed directly in units of minutes per readout period (nominally per week or per month). A printer-type readout will display the data in decimal form. An alternate magnetic-tape readout will be in binary, in a version of machine-readable "Kansas city standard." In either case, the 
output record will include a unit serial number, a program revision number, and a serial day count since last power-up. Tape output will be multiply redundant, and printed output will contain a checksum for data verification. The total number of counts in each separate histogram must all be equal to the number of data accumulation intervals (1-minute periods) since the last reset. This multi-way check will provide a stringent test of the processor, memory, and data recovery. The unit and program identification together with day count should allow unambiguous identification of a data record.

For program development, EPROM programming, data tape reading and field unit testing, a host unit will be required which is capable of communicating with a standard terminal. The RCA CDPl8S020 evaluation kit meets this requirement inexpensively.

\section{CONCLUSION}

The microprocessor unit seems to satisfy all the requirements of a wind prospector's instrument. This device:

- is inexpensive,

- works with all commonly used wind instruments,

- is small and light,

- uses little power, and

- is capable of providing detailed statistical summaries of wind data at a prospective wind turbine site.

This instrument promises to be a useful tool for early phases of site evaluation. 


\section{REFERENCES}

1. Fowler, William B., "Versatile Wind Analyser for Long Unattended Runs Using C-MOS," Journal of Physics E: Scientific Instruments 8 , pp. 713-714 (1975).

2. U.S. Patent \#4,011,752. 
PNL

Report No.: PNL-2514

Date:

No. of

Copies

OFFSITE

A. A. Churm

DOE Chicago Patent Troup

9800 South Cass Avenue

Argonne, IL 60439

G. P. Tennyson

Department of Energy

600 E Street, N.W.

Washington, DC 20545

283
No. of

Copies

10

Ben Wolff

American Wind Energy Association c/o Windworks

P.0. Box 329, Route 3

Mukwonago, WI 53149

Richard Katzenberg

American Wind Energy Association

Natural Power Inc.

New Boston, NH 03070

E. J. Warchol

Bonneville Power Administration

P.0. Box 3621

Portland, OR 97225

S. J. Hightower

Bureau of Reclamation

Denver Federal Center

Bldg. 67 Code 254

Denver, CO 80225

M. Ginosar

California Solar Energy

Commission

Energy, Resources Conservation

\& Development Commission

1111 Howe Avenue, Mai1 Stop 15

Sacramento, CA 95825

Robert Ba11

Center for the Environment \&

Man, Inc.

275 Windsor Street

Hartford, CT 06120

Dr. K. C. Spengler

American Meteorological Society

45 Beacon Street

Boston, MA 02108 
Dr. R. J. Hawks

Clarkson College

Potsdam, NY 13676

Dr. R. N. Meroney

Colorado State University

Fort Collins, Co 80523

E. H. Gilmore

Department of Agriculture

Agriculture Research Service

Bushland, TX 79012

L. A. Li1 jedah 1

Department of Agriculture

Agriculture Wind Energy Program

Building 001 Room 126 BARC-West

Beltsville, MD 20705

Douglas G. Fox

Department of Agrculture

Forest and Mountain Meteorology

Rocky Mountain Forest and Range

Experiment Station

240 West Prospect St.

Fort Collins, CO 80521

Major T. E. Kullgran

Department of the Air Force

USAF Academy

CO 80840

Jay Tappan

Department of Energy

State of Oregon

Labor \& Industries Building

Room 111

Salem, OR 97310

Harry Moses

Department of Energy

Division of Biomedical \&

Environmental Research

Mai1 Stop E-201

Washington, DC 20545
Carl Miner TAN-604

EG\&G Idaho, Inc.

P.0. Box 1625

Idaho Falls, ID 83401

Dr. Edgar Demeo

Electric Power Research

Institute

3412 Hillview Avenue

Palo Alto, CA 94303

Jim Lerner

Energy Resources Conservation and Development Commission

California Solar Energy Office

Mail Stop 15

Sacramento, CA 95825

Dr. W. Frost

FWG Associates, Inc.

R. R. 3 Box 331

Tullahoma, TN 37388

L. Krawitz

General Electric Company

P.0. Box 8555

Philadelphia, PA 19101

R. C. Koch

Geomet, Inc.

15 Firstfield Road

Gaithersburg, MD 20760

C. G. Justus

Georgia Institute of

Technology

Atlanta, GA 30332

Darryl Tompkins

JBF Scientific Corporation

1925 North Lynn Street

Suite 308

Arlington, VA 22209 
Dr. J. B. Knox

Lawrence Livermore Laboratory

University of California

P.0. Box 808

Livermore, CA 94550

M. Abbey Page

Maine Office of Energy

Resources

55 Capitol

Augusta, ME 04330

S. M. Howard

Meteorology Research, Inc.

P.0. Box 637

Altadena, CA 91001

Phillip French

NASA Scientific and Technical

Information Facility

P.0. Box 8757

Baltimore/Washington

International Airport

MD 21240

R. A. Wolf

NASA/Lewis Research Center

Mail Stop 500-201

Cleveland, $\mathrm{OH} 44135$

M. J. Changery

National Oceanic \& Atmospheric

Administration

National Climatic Center

Federal Building

Asheville, NC 28801

Ms. Peggy McDonald

N. E. Solar Energy Center

70 Memorial Drive

Cambridge, MA 02142

M. W. Edelstein

North American Weather

Consultants

600 Norman Firestone Road

Goleta, CA 93017
R. B. Corotis

Northwestern University

Evanston, IL 60201

E. W. Hewson

Oregon State University

Corvallis, OR 97331

S. C. Crow

Poseidon Research

11777 San Vicente Blvd.

Suite 641

Los Angeles, CA 90049

Dr. F. M. Vukovich

Research Triangle Institute

P.0. Box 12194

Research Triangle Park

NC 27709

Terry J. Healy

Rockwell International

Rocky Flats Plant

P.0. Box 464

Golden, C0 80401

R. E. Akins/J. W. Reed

Sandia Laboratories

Division 5443

P.0. Box 5800

Albuquerque, NM 87115

R. M. Traci

Science Applications, Inc.

P.0. Box 2351

La Jolla, CA 92038

D. M. Hardy

Solar Energy Research

Institute

1536 Cole Blvd.

Golden, CO 80401

Dr. C. M. Bhumralkar

Stanford Research

Institute, Int'1

Menlo Park, CA 94025 
PNL DISTRIBUTION

No. of

No. of

Copies

Copies

Dr. T. Wentink, Jr. University of Alaska

2

DOE Richland Operations

Fairbanks, AK 99701

office

Dr. P. Yuen

University of Hawai at Manoa

Holmes Hall 240

54

2540 Dole Street

G. L. Liffick

H. E. Ransom

Honolulu, HI 96822

Battelle-Northwest

C. E. Duchon

University of $0 \mathrm{klahoma}$

200 Felgar Street

Norman, OK 73069

Dr. N. K. Wagner

University of Texas

Austin, TX 78712

Dr. M. Garstang

University of Virginia

Charlottesville, VA 22903

Dr. R. W. Marrs

University of Wyoming

Laramie, WY 82071

W. C. Cliff

R. L. Conley

J. C. Doran

R. L. Drake

P. A. Ekstrom

C. E. Elderkin

R. K. Hadlock

M. M. Orgill

W. T. Pennell

E. H. Phinney

J. V. Ramsdell

D. S. Renne

C. L. Simpson

M. G. Verholek

L. L. Wende 11

Technical Information

Technical Publications

Ms. Susan Hosch

Washington State Energy Office

400 E. Union Ave. 1st. Floor

Olympia, WA 98504

Prof. Kent Rowe

Wichita State University

Box 444

Wichita, KS 67208 